\title{
Penerapan Pembelajaran Realistic Mathematics Education (RME) untuk Meningkatkan Kemampuan Pemecahan Masalah Siswa di Sekolah Dasar
}

\author{
Mimi Rahmi Rosneli ${ }^{1}$, Fadhilaturrahmi ${ }^{2}$, Adityawarman Hidayat ${ }^{3}$ \\ Program Studi PGSD FKIP Universitas Pahlawan Tuanku Tambusai \\ Email : Mimirahmi07@gmail.com
}

\begin{abstract}
Abstrak
Penelitian ini dilatarbelakangi oleh rendahnya kemampuan pemecahan masalah siswa pada pembelajaran Matematika di kelas V SDN 002 Muara Jalai Kecamatan Kampar Utara Kabupaten Kampar. Salah satu solusi untuk mengatasi masalah ini dengan menggunakan pembelajaran RME. Dengan demikian tujuan penelitian ini adalah untuk mengetahui dan mendeskripsikan RME untuk meningkatkan kemampuan pemecahan masalah siswa materi pecahan pada mata pelajaran Matematika siswa kelas V SD. Metode penelitian ini menggunakan penelitian tindakan kelas (PTK) yang dilaksanakan sebanyak dua siklus dan setiap siklus dilaksanakan 2 pertemuan. Peneliti ini dilaksanakan pada SDN 002 Muara Jalai dengan subjek penelitian adalah siswa kelas V SD. Pengumpulan data dalam penelitian ini menggunakan teknik observasi dan dokumentasi. Peningkatan kemampuan pemecahan masalah siswa pada mata pelajaran Matematika dari sebelum tindakan dengan rata-rata persentase $57,25 \%$ dengan kategori kurang, dengan menggunakan pembelajaran RME maka terjadi peningkatan siklus 1 dengan persentase 70,57\% dengan kategori cukup, sedangkan rata-rata siklus 2 kemampuan pemecahan masalah dengan menggunakan pembelajaran RME terjadi peningkatan dengan rata-rata $84,91 \%$ dengan kategori baik. Jadi, pembelajaran Matematika dengan pembelajaran RME dapat meningkatkan kemampuan Pemecahan masalah siswa kelas V SDN 002 Muara Jalai.
\end{abstract}

\section{Kata Kunci: Pembelajaran, RME, Pemecahan Masalah}

\section{PENDAHULUAN}

Matematika adalah ilmu yang abstrak dan deduktif. Menurut Andriani dan Hariyani (2013 : 13) Matematika diajarkan disekolah membawa misi yang sangat penting, yaitu mendukung ketercapaian tujuan pendidikan nasional. Secara umum tujuan pendidikan matematika 
di sekolah dapat digolongkan menjadi: Tujuan yang bersifat formal, menekankan kepada menata penalaran dan membentuk kepribadian siswa; Tujuan yang bersifat material, menekankan kepada kemampuan memecahkan masalah dan menerapkan matematika. Secara lebih terinci, tujuan pembelajaran matematika dipaparkan pada buku standar kompetensi mata pelajaran matematika sebagai berikut; (a) kepada kemampuan memecahkan masalah dan menerapkan matematika. Secara lebih terinci, tujuan pembelajaran matematika dipaparkan pada buku standar kompetensi mata pelajaran matematika sebagai berikut; Melatih cara berfikir dan bernalar dalam menarik kesimpulan, misalnya melalui kegiatan penyelidikan, eksplorasi, eksperimen, menunjukkan kesamaan, perbedaan, konsistensi dan ikonsistensi; (b) Mengembangkan aktivitas kreatif yang melibatkan imajinasi, intuisi, dan penemuan dengan mengembangkan pemikiran divergen, orisinil, rasa ingin tahu, membuat prediksi dan dugaan, serta mencoba-coba; (c) Mengembangkan kemampuan memecahkan masalah,

Mengembangkan kemampuan menyampaikan informasi atau mengkomunikasi kan gagasan antara lain melalui pembicaraan lisan, grafik, peta, diagram, dalam menjelaskan gagasan.

Undang-Undang Sistem Pendidikan Nasional No. 20 Tahun 2003 (Permendikbud, 2014) pasal 1 ayat 1, menjelaskan bahwa: Pendidikan adalah usaha sadar dan terencana untuk mewujudkan suasana belajar dan proses pembelajaran agar siswa secara aktif mengembangkan potensi dirinya untuk memiliki kekuatan spiritual kegamaan, pengendalian diri, kepribadian, kecerdasan, ahlak mulia, serta keterampilan yang diperlukan dirinya, masyarakat, bangsa dan negara.

Secara umum tujuan pendidikan adalah untuk mengubah segala macam kebiasaan tidak baik yang ada dalam diri manusia menjadi kebiasaan baik yang terjadi selama masa hidup, dengan tujuan untuk meningkatkan kualitas diri menjadi pribadi yang mampu bersaing dan menjawab berbagai tantangan di masa depan. Adapun tujuan pendidikan nasional seperti yang tercantum dalam UU No. 20 Tahun 2003 (BSNP, 2016), tentang Sistem Pendidikan Nasional yang menyatakan bahwa:Pendidikan nasional berfungsi untuk mengembang kan kemampuan dan membentuk watak serta peradaban bangsa yang bermartabat dalam rangka mencerdaskan bangsa, bertujuan untuk berkembang nya potensi peserta didik agar menjadi manusia yang beriman dan bertakwa kepada Tuhan Yang Maha Esa, berakhlak mulia, sehat, berilmu, cakap, kreatif, mandiri, dan menjadi warga negara yang demokrasi serta bertanggungjawab.

Salah satu kenyataan di lapangan adalah di sekolah SDN 002 Muara Jalai. Dalam pembelajaran matematika banyak siswa yang belum 
mampu mengembangkan kemampuan pemecahan masalah, dan belum bisa menyelesaikan soal-soal cerita dalam matematika.

Salah satu faktor penyebab rendahnya pemecahan masalah matematika siswa yaitu ketika siswa tidak memiliki minat atau tidak memilki kepercayaan bahwa masalah yang dipelajari sulit untuk dipecahkan, maka mereka akan merasa enggan untuk mencoba, kemudian siswa yang mengalami kelemahan dalam percobaan dan pengumpulan informasi akan mengalami kesulitan, dan kemungkinan ada siswa yang tidak aktif dalam pembelajaran.

Dengan mengajukan masalah kontekstual, siswa secara bertahap dibimbing untuk mengetahui konsep matematika. Siswa juga diharapkan dapat menggunakan daya nalar untuk memecahkan suatu masalah yang disajikan. Jadi seorang guru matematika benar-benar berarti jika dalam pembelajaran matematika dapat menghubungkan dengan kehidupan sehari-hari.

Kemampuan pemecahan masalah adalah kegiatan menyelesaikan soal cerita, menyelesaikan soal yang tidak rutin dalam kehidupan seharihari, mengaplikasikan matematika dalam kehidupan sehari-hari atau keadaan lain dan suatu usaha mencari jalan keluar dari suatu kesulitan guna mencapai suatu tujuan yang tidak segera dapat dicapai.

Berdasarkan uraian di atas dapat disimpulkan bahwa penelitian ini bertujuan untuk mengetahui apakah penerapan pembelajaran Realistic Mathematic Education (RME) dapat meningkatkan kemampuan pemecahan masalah dalam pembelajaran matematika sekolah dasar tahun 2019/2020.

Menurut Wijaya (2011 : 20-21) menyatakan bahwa kebermaknaaan konsep matematika merupakan konsep utama dari RME. Proses belajar siswa hanya akan terjadi jika pengetahuan (knowledge) yang dipelajari bermakna bagi siswa (Freudenthal,1991). Suatu pengetahuan akan menjadi bermakna bagi siswa jika proses pembelajaran dilaksanakan dalam suatu konteks (CORD, 1999) atau pembelajaran menggunakan permasalahan realistik. Suatu masalah realistik tidak harus selalu berupa masalah yang ada di dunia nyata (real-world problem) dan bisa ditemukan dalam kehidupan sehari-hari siswa. Suatu masalah disebut "realistik" jika masalah tersebut dapat dibayang kan (imagineanle) atau nyata (real) dalam pikiran siswa.

Menurut Sumarmo (dalam Firdaus,2009) mengartikan pemecahan masalah sebagai kegiatan menyelesaikan soal cerita, menyelesaikan soal yang tidak rutin, mengaplikasikan matematika dalam kehidupan seharihari atau keadaan lain, dan membuktikan atau menciptakan atau menguji konjektur. Berdasarkan pengertian tersebut dalam pemecahan masalah 
matematika tampak adanya kegiatan pengembangan daya matematika (mathematical power) terhadap siswa.

Menurut Branca (dalam Roebyanto dan Harmini 2017 : 15) menyatakan bahwa menegaskan bahwa terdapat tiga interprestasi umum mengenai pemecahan masalah, yaitu 1) pemecahan masalah sebagai tujuan (goal) yang menekankan pada aspek mengapa matematika di ajarkan. Hal ini berarti bahwa pemecahan masalah bebas dari materi khusus. Sasaran utama yang ingin dicapai adalah bagaimana cara memecahkan suatu masalah matematika; 2) pemecahan masalah sebagai proses (process) diartikan sebagai kegiatan yang aktif. Dalam hal ini penekanan utamanya terletak pada metode, strategi atau prosedur yang digunakan siswa dalam menyelesaikan masalah hingga mereka menemukan jawaban; dan 3) pemecahan masalah sebagai keterampilan (basic skill) menyangkut dua hal yaitu (a) keterampilan umum yang harus dimiliki siswa untuk keperluan evaluasi dan (b) keterampilan minimum yang diperlukan siswa agar dapat mengaplikasikannya dalam kehidupan sehari-hari. Memperhatikan rekomendasi dari NCTM dan pendapat Branca tentang pemecahan masalah matematika, maka dapat dikatakan bahwa pemecahan masalah tidak hanya berfungsi sebagai pendekatan, tetapi juga sebagai tujuan (Lovit dan Lowe, 1992).

Berdasarkan Observasi lapangan yang dilakukan peneliti di SDN 002 Muara Jalai di kelas $\mathrm{V}$ bahwa dalam pembelajaran matematika siswa dikatakan tuntas apabila nilainya sama dengan KKM atau lebih tinggi dari KKM. Berdasarkan data hasil belajar siswa terungkap bahwa masih banyak siswa yang tergolong rendah dari 16 orang siswa hanya 9 siswa $(56,25 \%)$ yang mencapai KKM, dan 7 siswa $(43,75 \%)$ belum mencapai nilai KKM. Berdasarkan latar belakang tersebut maka peneliti merekomendasikan penelitian dengan judul "Penerapan Pembelajaran Realistic Mathematics Education (RME) untuk Meningkatkan Kemampuan Pemecahan Masalah Siswa di Sekolah Dasar"

\section{METODE PENELITIAN}

Penelitian tentang "Penerapan pembelajaran RME untuk meningkatkan kemampuan pemecahan masalah siswa sekolah dasar". Menggunakan metode Penelitian Tindakan Kelas (PTK). Menurut Wardhani \& Wihardit (2010 : 14) menyatakan bahwa Penelitian Tindakan Kelas (PTK) penelitian dalam bidang sosial yang menggunakan refleksi diri sebagai metode utama, dilakukan oleh orang yang terlibat didalamnya serta bertujuan untuk melakukan perbaikan dalam berbagai aspek.

Subjek dalam penelitian ini adalah siswa kelas V SDN 002 Muara Jalai tahun ajaran 2019/2020, yang berjumlah 19 orang siswa, yang terdiri 
dari 11 orang siswa laki-laki dan 8 orang siswa perempuan. Adapun pihakpihak yang terlibat dalam penelitian ini adalah sebagai berikut:

1. Mimi Rahmi Rosneli sebagai guru pratikan

2. Nurzan,S.Ag sebagai observer aktivitas guru

3. An'nas Tasya Qoriah Hasibuan sebagai observer aktivitas siswa

Tiap siklus dilaksanakan 2 kali pertemuan. Pelaksanaan masingmasing tiap siklus mengikuti tahap - tahap perencanaan, tindakan, observasi dan refleksi. Instrumen penelitian pada penelitian ini yaitu:

1. Perangkat Pembelajaran (Silabus dan Rencana Pelaksanaan Pembelajaran (RPP))

Silabus merupakan penjebaran dari standar kompetensi dan kompetensi dasar yang bertujuan agar peneliti mempunyai acuan yang jelas dalam melakukan tindakan pada suatu mata pelajaran yang terdiri dari standar kompetensi, kompetensi dasar, materi pokok, indikator, penilaian yang terdiri dari teknik, bentuk instrumen, alokasi waktu, serta sumber belajar.

RPP disusun secara sistematis yang berisikan adalah panduan langkah-langkah yang dilakukan oleh seseorang guru dalam kegiatan pembelajaran yang disusun dalam skenario kegiatan terdiri dari kegiatan pendahuluan, kegiatan inti, dan kegiatan penutup yang berpedoman pada langkah-langkah pembelajaran RME. Komponen penting dalam rencana pembelajaran meliputi: SK, KD, Indikator, Tujuan pembelajaran, Sumber belajar dan penilaian hasil belajar.

2. Lembar Observasi

Lembar observasi ini digunakan untuk menilai kegiatan yang dilakukan peneliti dalam pelaksanaan penelitian, observer akan mengisi lembaran observasi yang mencatat kegiatan peneliti dari awal sampai akhir dalam penyajian materi pembelajaran. Lembar observasi terdiri dari dua bagian, yaitu lembar observasi aktivitas guru dan lembar observasi aktivitas siswa.

3. LTS dan Soal Tes

Lembar Tugas Siswa (LTS) berisikan indikator dan kegiatan yang berisikan langkah-langkah kegiatan atau petunjuk tugas siswa yang harus dikerjakan oleh masing-masing siswa sebagai bentuk pemahaman terhadap materi pelajaran. Tes hasil belajar siswa digunakan untuk mengetahui hasil belajar siswa setelah proses pembelajaran. Tes yang diberikan adalah tes tertulis.

Teknik analisis data yang dikumpulkan dalam penelitian ini adalah perpaduan dari data kualitatif dan data kuantitatif.

1. Deskriptif Kualitatif 
Deskriptif kualitatif digunakan untuk menganalisis data kemampuan pemecahan masalah selama proses pembelajaran berlangsung. Data kualitatif ini diperoleh dari data non tes yaitu Observasi.

2. Deskriptif kuantitatif

Deskriptif kuantitatif akan digunakan untuk mendeskripsikan peningkatan kemampuan pemecahan masalah dengan penguasaan materi yang diajarkan guru.

Dengan demikian analisis data dari penelitian ini adalah analisis deskripsi kualitatif dan deskripsi kuantitatif. Untuk menghitung hasil belajar dapat dihitung dengan menggunakan rumus sebagai berikut:

\section{$P=\sum$ skor yang diperoleh $\times 100$ \\ Skor maxsimum \\ Dengan P sebagai nilai akhir.}

Siswa dikatakan tuntas apabila nilainya sama dengan KKM atau lebih tinggi dari KKM yaitu 65. Menentukan nilai klasikal rumus yang digunakan yaitu:

$$
\mathrm{KK}=\frac{\text { Siswa yang tuntas }}{\text { Jumlah seluruh siswa }} \times 100
$$

Keterangan:

$\mathrm{KK}=$ Ketuntasan Klasikal

Nilai kemampuan pemecahan masalah yang diperoleh dari perhitungan kemudian dikualifikasikan sesuai dengan tabel berikut:

Tabel 1.

Kategori Kemampuan

Pemecahan Masalah Siswa

\begin{tabular}{|c|c|}
\hline Nilai Siswa & Kualifikasi \\
\hline $90 \%-100 \%$ & Baik Sekali \\
\hline $80 \%-89 \%$ & Baik \\
\hline $70 \%-79 \%$ & Cukup \\
\hline$<70 \%$ & Kurang \\
\hline
\end{tabular}

(Adjie dan Rostika, 2006:246)

Menurut Adjie dan Rostika (2006:246) jika ketuntasan klasikal siswa telah mencapai $80 \%$ dari seluruh siswa, maka hasil belajar siswa secara klasikal telah tercapai dengan baik. 


\section{HASIL DAN PEMBAHASAN}

\section{A. Deskripsi Sebelum Tindakan}

Berdasarkan observasi awal pada tanggal 23 Februari 2019 di SDN 002 Muara Jalai secara umum proses pembelajaran Matematika di kelas masih banyak siswa yang belum mampu mengembangkan kemampuan pemecahan masalah, dan belum bisa menyelesaikan soal cerita dalam Matematika. Dalam pembelajaran matematika siswa dikatakan tuntas apabila nilainya sama dengan KKM atau lebih tinggi dari KKM. Berdasarkan data hasil belajar siswa terungkap bahwa masih banyak siswa yang tergolong rendah dari 16 orang siswa hanya 9 siswa $(56,25 \%)$ yang mencapai $\mathrm{KKM}$, dan 7 siswa $(43,75 \%)$ belum mencapai nilai KKM.

\section{B. Deskripsi Hasil Tindakan Tiap Siklus \\ Siklus 1}

Kemampuan pemecahan masalah siswa diketahui dengan dilakukannya tes kemampuan pemecahan masalah siswa dengan materi pecahan. Soal tes terdiri dari 5 soal essay yang meliputi lima indikator kemampuan pemecahan masalah. Berdasarkan data yang diperoleh, persentase hasil tes kemampuan pemecahan masalah siswa pada siklus 1 dapat dilihat pada tabel 2 berikut ini.

Tabel 2

\section{Persentase Kemampuan Pemecahan Masalah Siswa Siklus 1}

\begin{tabular}{|c|c|c|c|}
\hline No & Kriteria & Jumlah & Persentase \\
\hline 1 & Baik Sekali & 6 & $31,57 \%$ \\
\hline 2 & Baik & 3 & $15,78 \%$ \\
\hline 3 & Cukup & 1 & $5,26 \%$ \\
\hline 4 & Kurang & 9 & $47,36 \%$ \\
\hline
\end{tabular}

Berdasarkan pernyataan di atas maka persentase kemampuan pemecahan masalah siswa dapat dilihat dengan jelas pada diagram yang disajikan pada grafik 1 berikut ini:

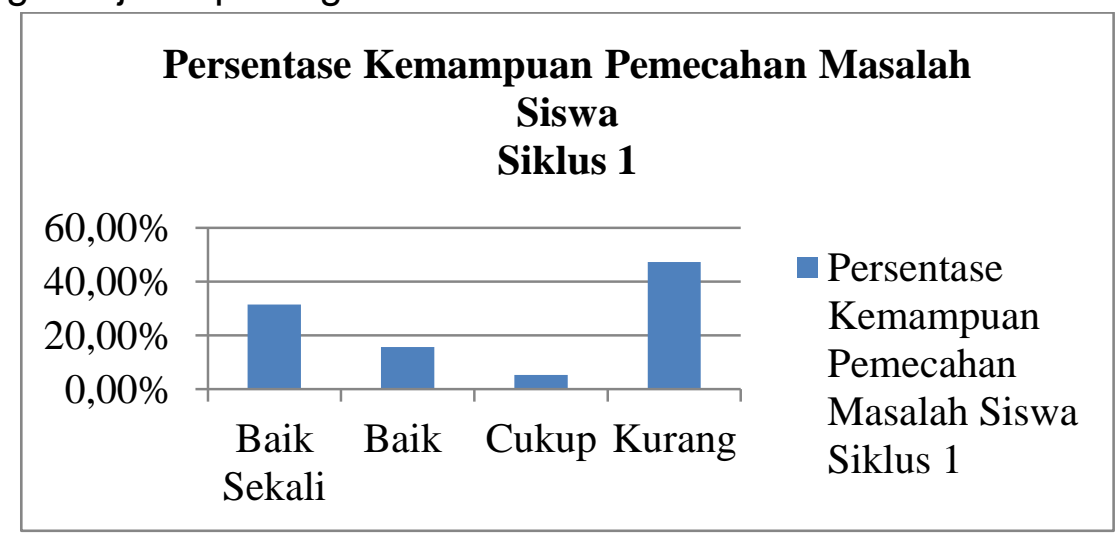

Grafik 1.

Diagram Persentase Kemampuan Pemecahan Masalah Siklus 1 


\section{Siklus 2}

Hasil kemampuan pemecahan masalah siswa pada siklus 2 juga diketahui dengan dilakukanya tes kemampuan pemecahan masalah dengan materi pecahan yang terdiri dari 4 soal essay. Berdasarkan data yang diperoleh, persentase hasil tes kemampuan pemecahan masalah siswa pada siklus 2 dapat dilihat pada tabel 3 berikut ini:

\section{Tabel 3.}

\section{Persentase Kemampuan Pemecahan Masalah Siswa Siklus 2}

\begin{tabular}{|c|c|c|c|}
\hline No & Kriteria & Jumlah & Persentase \\
\hline 1 & Baik Sekali & 7 & $36,84 \%$ \\
\hline 2 & Baik & 5 & $26,31 \%$ \\
\hline 3 & Cukup & 3 & $15,78 \%$ \\
\hline 4 & Kurang & 4 & $21,05 \%$ \\
\hline
\end{tabular}

Berdasarkan pernyataan di atas maka persentase kemampuan pemecahan masalah siswa dapat dilihat dengan jelas pada diagram yang disajikan pada gambar 4.2 dibawah ini:

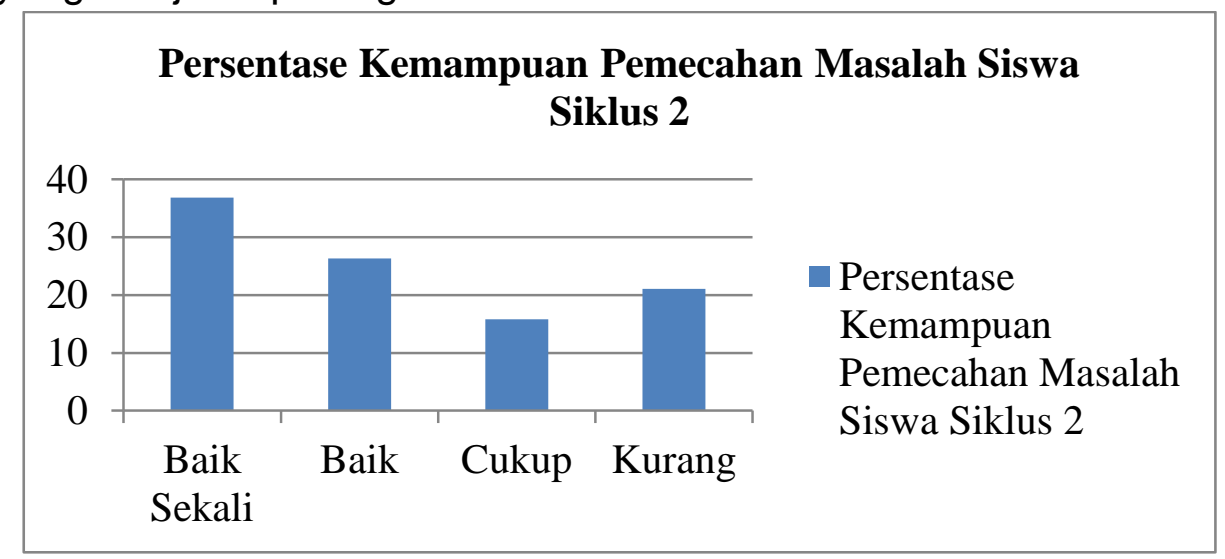

\section{Grafik 2}

\section{Diagram Persentase Kemampuan Pemecahan Masalah Siklus 2}

\section{SIMPULAN}

Kemampuan pemecahan masalah siswa kelas V SDN 002 Muara Jalai, nilai rata-rata siswa pada pratindakan adalah 57,25 dengan kategori "Kurang" (<70\%) pada siklus 1 meningkat menjadi 70,57 dengan kategori "Cukup"(70\%-79\%),kemudian pada siklus 2 mengalami peningkatan menjadi 83,727 dengan kategori "Baik" (80\%-89\%). Sedangkan presentase ketuntasan klasikal pemecahan masalah siswa pratindakan adalah 56,25\% (9 siswa) dengan kategori "Kurang" (<70\%), pada siklus 1 meningkat menjadi 63,15\% (12 siswa) dengan kategori "Kurang" (<70\%), kemudian pada siklus 2 meningkat menjadi $89.47 \%$ (17 siswa) dengan kategori "Baik" (80\%-89\%.) 


\section{DAFTAR PUSTAKA}

Adjie,Nahrowi \& Rostika,Deti. (2006). Konsep Dasar Matematika. Bandung: UPI PRESS

Andriani,Melly. (2013). Pembelajaran Matematika SD/MI. Pekanbaru: Benteng Media,CV.

Firdaus. (2009). Kemampuan Pemecahan Masalah Matematika.

Fitriani,Kartika \& Maulana. (2016). Meningkatkan Kemampuan Pemahaman Dan Pemecahan Masalah Matematis Siswa SD Kelas V Melalui Pendekatan Matematika Realistik, Volume 3, Nomor 1 .

Komariah. (2007). Model Pemecahan Masalah Melalui Pendekatan Realistik Pada Pembelajaran Matematika SD.

Mansyur,zulfikar. (2014).Kemampuan Pemecahan Masalah Matematis

Mairing,Jackson. (2018). Pemecahan Masalah Matematika cara siswa memperoleh jalan untuk berpikir kreatif dan sikap Positif. Bandung: Penerbit Alfabeta.

Muslich,Masnur. (2012). Melaksanakan PTK Itu Mudah Classroom Action Research). Malang: Bumi Aksara.

Roebyanto.Goenawan \& Harmini.Sri. (2017). Pemecahan Masalah Matematika Untuk PGSD. Bandung: PT Remaja Rosdakarya.

Rahmawati.Puji. (2011). Pengembangan Model Pembelajaran Berbasis RME Untuk Meningkatkan Kemampuan Pemecahan masalah Siswa Di SD.

Syarif,Mohamad.(2015). Strategi Pembelajaran:Teori dan Praktik Di Tingkat Pendidikan Dasar. Jakarta: RajaGrafindo Persada.

Sarbiyono. (2016). Penerapan Pendekatan Matematika Realistik Terhadap Kemampuan Pemecahan Masalah Matematis Siswa, Volume 1, Nomor 2.

Shoimin,Aris. (2014). 68 Model Pembelajaran Inovatif dalam Kurikulum 2013. Yogyakarta: Ar-Ruzz Media.

Unggah,Jasa. (2010). Penelitian Tindakan Kelas (Classroom Action Research). Yogyakarta: Penerbit Gava Media

Ulvah,Shovia. (2016). Kemampuan Pemecahan Masalah Matematis Siswa Ditinjau melalui Model Pembelajaran SAVI dan Konvensional, Volume 2, Nomor 2.

Wijaya,Ariyadi. (2011). Pendidikan Matematika Realistik Suatu Alternatif Pendekatan Pembelajaran Matematika. Yogyakarta: Geraha IImu.

Wardhani,Igak \& Wihardit,Kuswaya. (2010). Penelitian Tindakan Kelas. Jakarta: Universitas Terbuka.

Wahyuni,Rini. (2016). Upaya Peningkatan Kemampuan Pemecahan Masalah Matematis Siswa Dengan Pendidikan Matematika Realistik Indonesia, Volume 5, Nomor 2. 